\title{
The influence of oceanic and lagoonal plume waters on otolith chemistry
}

\author{
Heather M. Patterson, Michael J. Kingsford, and Malcolm T. McCulloch
}

\begin{abstract}
To determine how ocean and lagoonal plume waters from within the same reef were reflected in the chemical composition of otoliths, we conducted an experiment over three consecutive summers where conditions of temperature and food were held constant. Presettlement Pomacentrus coelestis were held in replicate tanks of the two water masses for 9 days. The sagittae were then analyzed at high spatial resolution $(5 \mu \mathrm{m} \times 50 \mu \mathrm{m} \times 4 \mu \mathrm{m})$ using laser ablation inductively coupled plasma mass spectrometry. $\mathrm{Ba} / \mathrm{Ca}$ and $\mathrm{Sr} / \mathrm{Ca}$ varied between water masses and the rank of these elemental ratios changed among years. Although the reason for this change in rank is not known, likely mechanisms include upwelling and (or) the episodic appearance of phytoplankton blooms inside the lagoon. This is the first demonstration that the elemental signatures of otoliths can vary significantly over small spatial scales in reef systems in the absence of confounding factors, thus complicating studies attempting to discriminate reef-based stocks or elucidate natal origins using otolith chemistry.
\end{abstract}

\begin{abstract}
Résumé : Afin de déterminer comment les eaux des panaches de l'océan et de la lagune dans un même récif se reflètent dans les composition des otolithes, nous avons procédé à une expérience dans des conditions constantes de température et d'alimentation au cours de trois étés consécutifs. Nous avons gardé des Pomacentrus coelestis dans un double jeu d'aquariums contenant chacun de l'eau de l'une des deux masses d'eau pendant 9 jours. Nous avons ensuite analysé les sagittas avec une forte résolution spatiale $(5 \mu \mathrm{m} \times 50 \mu \mathrm{m} \times 4 \mu \mathrm{m})$ par ablation laser et un couplage de la spectrométrie de masse et de la spectrométrie d'émission à plasma par induction (spectrométrie LA-ICP-MS). Les rapports $\mathrm{Ba} / \mathrm{Ca}$ et $\mathrm{Sr} / \mathrm{Ca}$ différent entre les masses d'eau et le rang de ces rapports d'éléments change d'une année à l'autre. Bien que la cause de ce changement de rang reste inconnue, les mécanismes possibles incluent la présence de résurgences et $(\mathrm{ou}) \mathrm{d}$ 'effloresences de phytoplancton à l'intérieur de la lagune. C'est la première fois qu'on démontre que la signature des éléments dans les otolithes peut varier sur de petites échelles spatiales dans un système lagunaire en l'absence de facteurs confondants, ce qui complique les études qui cherchent, à l'aide de la chimie des otolithes, à distinguer les stocks associés aux divers récifs et à retrouver les origines de ces stocks.
\end{abstract}

[Traduit par la Rédaction]

\section{Introduction}

Over the past 10 years, otolith chemistry has emerged as an alternative or complimentary method to tagging and genetic studies for examining the population structure as well as the movement patterns of marine fishes. The geochemical signature encoded within the aragonite matrix of the otolith can act as a natural tag. Otolith chemistry has been used to address issues such as determining nursery habitats (Gillanders and Kingsford 1996, 2000), examining stock structure (Campana et al. 1994; Patterson et al. 1999), estimating natal homing rates in a population (Thorrold et al. 2001), and estimating larval retention near reefs (Swearer et al. 1999). Like other biogenic carbonates, such as corals and foraminifera, otoliths may provide useful proxies for the reconstruction of temperature and environmental histories
(Patterson et al. 1993; Bath et al. 2000). Such research relies on the assumption that the chemical signature of the otolith to some degree reflects the chemical signature of the water in which the organism resides. This assumption appears to be valid for marine fish, especially as otolith chemistry has proven to be useful in distinguishing geographically separated groups (see Campana (1999) for a review).

However, otolith deposition is a poorly understood process, and the synergies of ambient and physiological processes by which elements are deposited in the otolith matrix are complex. One of the most pressing issues yet to be fully addressed is the importance of microscale differences to interpreting otolith chemistry results. Several studies have demonstrated variation in otolith chemistry over small spatial scales, which could make attempts to discriminate fish on larger spatial scales more difficult. For example, Wells et

Received 7 August 2003. Accepted 14 February 2004. Published on the NRC Research Press Web site at http://cjfas.nrc.ca on 23 July 2004.

J17687

H.M. Patterson ${ }^{1,2}$ and M.J. Kingsford. School of Marine Biology and Aquaculture, James Cook University, Townsville, Queensland 4811, Australia.

M.T. McCulloch. Research School of Earth Sciences, The Australian National University, Canberra, Australian Capital Territory 0200, Australia.

${ }^{1}$ Corresponding author (e-mail: hmpatt@unimelb.edu.au).

${ }^{2}$ Present address: Department of Zoology, University of Melbourne, Victoria 3010, Australia. 
al. (2003) noted that attempts to examine large-scale patterns of fish movement in a freshwater system might be confounded by fine-scale variation in water chemistry (i.e., at the individual stream level). Similarly, Thorrold et al. (1998) found elemental differences in the otoliths of fish collected from different sites within the same river, whereas Kingsford and Gillanders (2000) found significant differences in both the otoliths and eye lenses of fish collected from different depths within the same site. In addition, several studies have documented temporal variation in otolith signatures both within (Thorrold et al. 1998; Thorrold and Shuttleworth 2000) and among years (Patterson et al. 1999; Campana et al. 2000; Gillanders 2002), which could potentially confound the interpretation of spatial variability in otolith signatures. Thus, if otolith signatures are to be used for management purposes, these signatures will likely need to be recalibrated periodically (Campana et al. 2000; Gillanders 2002).

Studies examining otolith chemistry in general, and smallscale differences in particular, have been largely restricted to coastal areas (but see Patterson et al. 1999; Swearer et al. 1999), where differences in water chemistry, and therefore otolith chemistry, are more likely to be detectable due to terrestrial inputs and mixing processes (Thorrold et al. 2002). However, as coral reefs have become increasingly threatened (Knowlton 2001), it has become important to understand the population dynamics of reef species to provide adequate protection. Otolith chemistry may prove to be a useful tool in elucidating issues of connectivity and natal origins of reef fish, but no study to our knowledge has examined differences in otolith chemistry at small spatial scales (i.e., hundreds of metres) in these systems, despite the potential importance of such differences in interpreting larger scale results.

Our novel approach was to use manipulative experiments conducted in the field to determine if the chemistry of reef fish otoliths varied between plume and inter-reef waters (hereafter referred to as ocean waters) at a single reef in the Great Barrier Reef. We experimentally exposed presettlement reef fish to these two water masses (ocean versus plume) in the absence of confounding exogenous factors (i.e., temperature and food differences) to determine if differences in otolith chemistry at small spatial scales existed and if these differences were consistent over time. We used Pomacentrus coelestis as the study species because they were abundant in the waters around the study site, were easily captured in light traps, and are known to be robust to experimentation. The otoliths from these fish were analyzed using laser ablation inductively coupled plasma mass spectrometry (LA-ICP-MS) at high spatial resolution.

\section{Materials and methods}

\section{Study site}

This study was conducted on One Tree Island (OTI) in the southern Great Barrier Reef $\left(23^{\circ} 30^{\prime} \mathrm{S}, 152^{\circ} 06^{\prime} \mathrm{E}\right)$ (Fig. 1). This type of platform reef is rare on the Great Barrier Reef; at low tide, the reef crest emerges and the lagoon water is isolated for 3-5 h until the next high tide (Maxwell 1968; Ludington 1979). This ponding behavior, in conjunction with the shallow nature of the lagoon, allows temperature differences of several degrees between the lagoon and sur-
Fig. 1. Map of OTI $\left(23^{\circ} 30^{\prime} \mathrm{S}, 152^{\circ} 06^{\prime} \mathrm{E}\right)$ off the eastern coast of Australia (inset) with the locations of the light traps depicted by squares. Solid squares indicate light traps that were fished in 2000 only and shaded squares indicate light traps that were fished during all years of the experiment. Water for the experimental plume treatments was taken just south of the light traps (shaded squares only) in the plume waters at the entrance of the lagoon, while ocean water was taken just north of the light traps (shaded squares only) outside the plume waters.

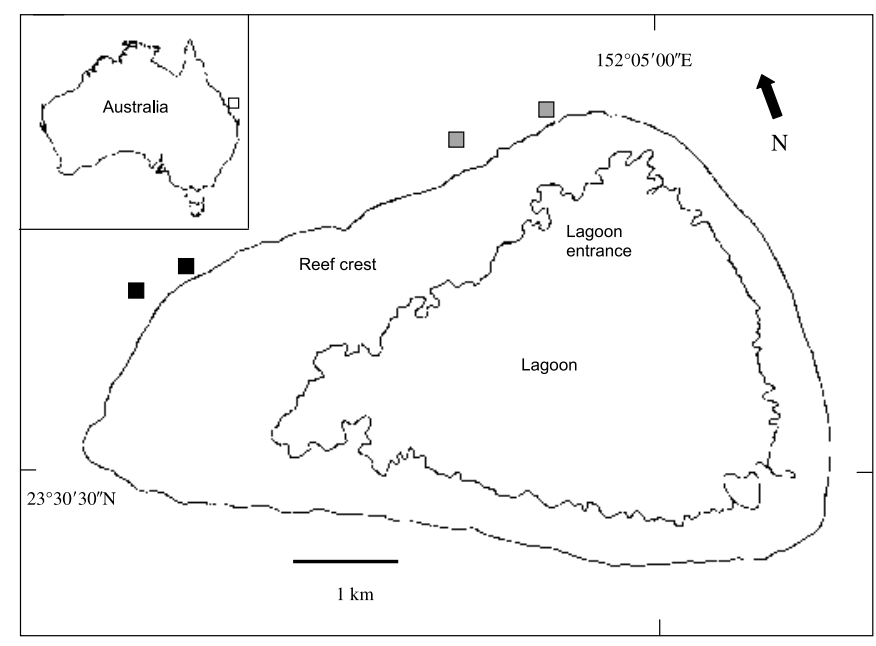

rounding ocean waters to develop (Atema et al. 2002). Thus, the geochemical properties of the lagoon water may develop in a distinct manner from ocean water. Transient, visible ebb tide plumes form on the leeward side of the reef (Atema et al. 2002), potentially exposing nearby organisms to lagoonal waters. Thus, OTI presented a unique opportunity to conduct a natural experiment examining the effects of the splitting and isolation of a single water mass on otolith chemistry at small spatial scales.

\section{Fish collections}

Presettlement $P$. coelestis were collected using two to four moored light traps at several sites within $100 \mathrm{~m}$ of the reef slope (Fig. 1) during three consecutive austral summer field seasons (2000-2002). Traps were illuminated for $3 \mathrm{~h}$ a night (2100-2200, 2400-0100, and 0300-0400) and were checked at the first morning high tide. Catches from the traps were sorted on the boat and nontarget species that were readily identifiable were recorded and returned to the ocean. Unknown and target species were taken to the laboratory to be counted and identified.

\section{Experimental design}

The experimental design for each year was nearly identical and differed only in the number of replicate fish placed in each tank at the beginning of the experiment (6 in 2000, 10 in 2001, and 3 in 2002). Experimental fish were allowed a minimum of $24 \mathrm{~h}$ to acclimate to experimental conditions before the start of the experiment. Three replicates of each treatment (plume water versus ocean water) were set up in 20-L tanks and replicate fish were randomly placed in each tank. Tanks were kept under shade cloth in a wet laboratory and aerated. Water was collected and changed daily ( 90\%). Fish were fed twice a day (morning and afternoon) with 
Artemia and wild zooplankton and the water temperature was recorded at each feeding (mean for all years and treatments \pm SE; morning feeding: $26.5{ }^{\circ} \mathrm{C} \pm 0.09$; afternoon feeding: $28.22{ }^{\circ} \mathrm{C} \pm 0.09$ ). For all years of the experiment, there were no significant differences in water temperature by tank nested in treatment (analysis of variance (ANOVA); morning: $F_{[1,4]}=0.09, p>0.05$; afternoon: $F_{[1,4]}=0.06, p>$ 0.05 ) or by treatment (ANOVA; morning: $F_{[1,4]}=2.61, p>$ 0.05 ; afternoon: $\left.F_{[1,4]}=5.13, p>0.05\right)$. Fish were maintained in this manner for a total of 9 days. At the end of the 9 days, three fish from each tank were frozen for elemental analysis.

\section{Sample preparation and analysis}

In the laboratory, standard length was measured and the sagittae were dissected in a laminar flow hood using only acid-washed plastic and glass instruments. The standard length of the $P$. coelestis used in the experiment (mean \pm $\mathrm{SE}=15.23 \mathrm{~mm} \pm 0.07$ ) did not differ between treatment groups for any year of the experiment (ANOVA; 2000: $F_{[1,16]}=3.31, p>0.05 ; 2001: F_{[1,16]}=1.43, p>0.05 ; 2002$ : $\left.F_{[1,16]}=2.4, p>0.05\right)$ or among years $\left(F_{[2,51]}=0.24, p>\right.$ $0.05)$. The otoliths were triple rinsed in Milli-Q water and were allowed to dry. Sagittae were embedded in Epofix resin and polished with grit size 800 lapping paper on a grinding machine and by hand until the primordium was visible and rings could be counted. Multiple otoliths (10 per slide) were then affixed in random order to a single slide with Crystalbond 509 adhesive in preparation for LA-ICP-MS.

Otoliths were analyzed using a Resonetics ArF excimer laser system coupled with a 7500 series Agilent ICP-MS (Table 1) (for a more extensive description of the system, see Eggins et al. (1998) or Sinclair (1999)). The calibration of the ICP-MS was achieved using NIST glass standard 612 (National Institute of Standards and Technology, Gaithersburg, Maryland). Relative standard deviation values were used as a measure of precision and were $<5 \%$ for the standard. Each otolith was pre-ablated to remove surface contamination using a mask in the shape of a square slit $\sim 530 \mu \mathrm{m} \times 530 \mu \mathrm{m}$. The pre-ablation procedure consisted of 10 individual laser pulses at $\sim 90 \mathrm{~mJ}$ energy, with each pulse estimated to remove $0.10 \mu \mathrm{m}$ (Eggins et al. 1998). The mask was then changed to a rectangular slit, producing a rastering (hereafter referred to as a laser footprint) $5 \mu \mathrm{m} \times 50 \mu \mathrm{m}$ running perpendicular to the increments with an average depth of $\sim 4 \mu \mathrm{m}$. The laser was pulsed at $10 \mathrm{~Hz}$ using $\sim 90 \mathrm{~mJ}$ energy across the shortest axis of the otoliths from one edge to the other passing through the sulcus and the primordium. This allowed approximately seven data points to be collected per laser footprint. Data points on the edge of footprints were not used for any analyses to ensure that there was no overlap between footprints. Background levels and standards were collected before each series began and after each series, with each series comprising a maximum of five otoliths.

Otoliths were analyzed for ${ }^{26} \mathrm{Mg},{ }^{43} \mathrm{Ca},{ }^{55} \mathrm{Mn},{ }^{88} \mathrm{Sr}$, and ${ }^{138} \mathrm{Ba}$ based on a preliminary analysis of three otoliths. Calcium was used as an internal standard, as it did not vary in concentration across the laser trajectory. Limits of detection ( $3 \sigma$ of mean blank values in parts per million) were calculated as follows: ${ }^{26} \mathrm{Mg}, 1.47 ;{ }^{43} \mathrm{Ca}, 0.11 ;{ }^{55} \mathrm{Mn}, 0.11 ;{ }^{88} \mathrm{Sr}$, $0.027 ;{ }^{138} \mathrm{Ba}, 0.014$. The Epofix resin was analyzed as well
Table 1. Operating parameters of the LA-ICP-MS used in this study.

\begin{tabular}{ll}
\hline LA-ICP-MS & Agilent 7500s \\
Acquisition mode & Time resolved \\
Coolant gas flow rate & $14 \mathrm{~L} \cdot \mathrm{min}^{-1}$ \\
Auxiliary gas flow rate & $1 \mathrm{~L} \cdot \mathrm{min}^{-1}$ \\
Carrier gas flow rate $(\mathrm{Ar})$ & $1.15 \mathrm{~L} \cdot \mathrm{min}^{-1}$ \\
Carrier gas flow rate $(\mathrm{He})$ & $0.3 \mathrm{~L} \cdot \mathrm{min}^{-1}$ \\
RF power & $1250 \mathrm{~W}$ \\
Dwell time & $20 \mathrm{~ms}$ (per mass) \\
Detector mode & Dual simultaneous \\
Time slice & $112.2 \mathrm{~ms}$ \\
Laser & Resonetics LPX120i \\
Laser type & ArF Excimer \\
Energy output & $100 \mathrm{~mJ}$ \\
Wavelength & $193 \mathrm{~nm}$ \\
Repetition rate & $10 \mathrm{~Hz}$ \\
Spot size & $150 \mu \mathrm{m} \times 1 \mathrm{~mm}$ \\
Crater size & $5 \mu \mathrm{m} \times 50 \mu \mathrm{m} \times 4 \mu \mathrm{m}$ \\
\hline
\end{tabular}

and was determined not to contribute any contamination to the otoliths, as the resin was several orders of magnitude lower in elemental concentration than the otoliths. The surface of the otoliths was also kept free of resin and Crystalbond, and the otoliths were pre-ablated before analysis to err on the side of caution.

\section{Image analysis}

After the otoliths were sampled with the LA-ICP-MS, the daily increments were counted and measured using an image analysis system to determine the position of the preexperimental and experimental portions of the otoliths. A drop of immersion oil was placed on each otolith to enhance its appearance and an image of each otolith was captured and saved at a magnification of 400x using a Leica DC300 digital video camera. Using the software package Leica IM50, the distance between each increment on the nonsulcal side of each otolith was measured; the sulcus of the otolith was not used in any analyses, as the increments in the sulcus were compressed and often difficult to discern and measure. Footprints, and the daily increments to which they corresponded, were also assigned a code based on the life history stage to which they were linked. The first three footprints from the dorsolateral margin of the primordium towards the ventrolateral margin of the otolith were designated the "natal region", while the fourth footprint through the start of the experiment was designated the "pre-experimental region". The last nine daily increments, corresponding to the 9 days of the experiment, were assigned to the "experimental region". It has previously been established with tetracycline marking that $P$. coelestis increments are deposited daily (Flood 2000). The footprints bordering a different life history region of the otolith were not used for any analyses.

\section{Data analysis}

Elemental data were normalized to $\mathrm{Ca}$ and expressed as molar ratios. Intensities were blank corrected, standardized to $\mathrm{Ca}$, and interpolated to NIST values to correct for possible instrument drift using an Excel macro. Data were tested 
Table 2. ANOVA results of $\ln (x+1)$-transformed elemental ratios before the start of the experiment.

\begin{tabular}{|c|c|c|c|c|c|c|c|c|c|}
\hline \multirow[b]{2}{*}{ Source } & \multirow[b]{2}{*}{ df } & \multicolumn{2}{|c|}{$\underline{\mathrm{Mg} / \mathrm{Ca}}$} & \multicolumn{2}{|c|}{$\mathrm{Mn} / \mathrm{Ca}$} & \multicolumn{2}{|l|}{$\mathrm{Sr} / \mathrm{Ca}$} & \multicolumn{2}{|c|}{$\mathrm{Ba} / \mathrm{Ca}$} \\
\hline & & MS & $F$ & MS & $F$ & MS & $F$ & MS & $F$ \\
\hline Year & 2 & 1.74 & $6.12 *$ & 0.08 & $1.66 \mathrm{~ns}$ & 0.008 & $1.99 \mathrm{~ns}$ & 0.06 & $0.50 \mathrm{~ns}$ \\
\hline Treatment & 1 & 0.83 & $0.77 \mathrm{~ns}$ & 0.05 & $0.60 \mathrm{~ns}$ & 0.004 & $0.57 \mathrm{~ns}$ & 0.01 & $0.04 \mathrm{~ns}$ \\
\hline Year $\times$ treatment & 2 & 1.07 & $3.75 \mathrm{~ns}$ & 0.08 & $1.61 \mathrm{~ns}$ & 0.008 & $2.02 \mathrm{~ns}$ & 0.27 & $2.17 \mathrm{~ns}$ \\
\hline Tank $($ year $\times$ treatment $)$ & 12 & 0.29 & $1.19 \mathrm{~ns}$ & 0.05 & $1.26 \mathrm{~ns}$ & 0.004 & $0.99 \mathrm{~ns}$ & 0.12 & $2.77 * *$ \\
\hline Residual & 36 & 0.24 & & 0.04 & & 0.004 & & 0.04 & \\
\hline
\end{tabular}

Note: $* p<0.05 ; * * p<0.01$; ns, not significant.

for homogeneity of variances using a Cochran's $C$ test and all elemental ratios were $\ln (x+1)$ transformed; data were found to be homogeneous after transformation. To analyze increments corresponding to both the pre-experimental and experimental phases, mixed-model ANOVAs for each elemental ratio $(\mathrm{Mg} / \mathrm{Ca}, \mathrm{Mn} / \mathrm{Ca}, \mathrm{Sr} / \mathrm{Ca}$, and $\mathrm{Ba} / \mathrm{Ca})$ were used. In this design, there were three factors (year, treatment, and tank nested within the year $\times$ treatment interaction term). Treatment was a fixed factor and year and tank were random factors.

We used discriminant function analyses to determine how accurately we could classify fish to experimental water mass treatment. It was determined with a Box's $M$ test that variance-covariance matrices were unequal. A quadratic discriminant function analysis was used, therefore, to determine how accurately otolith chemistry could distinguish fish from the different treatments by calculating a jackknife cross-validation. We acknowledge that this method produces classification accuracies higher than if a training data set were used. However, an independent data set was unavailable and using a subset of the experimental data was not practical given the small sample size per treatment and year. As there were two treatment groups per year that produced single canonical variates, we plotted those variates using jittered dot density plots to illustrate separation in multivariate space.

\section{Results}

\section{Pre-experiment}

No differences in otolith chemistry existed between the treatment groups and no interactions were detected prior to the start of the experiment (Table 2; Fig. 2). However, a significant year difference was found for $\mathrm{Mg} / \mathrm{Ca}$. In addition, there were differences among tanks nested in the year $\times$ treatment interaction term for $\mathrm{Ba} / \mathrm{Ca}$. This was not unexpected, as the fish collected for the experiment could have encountered different water masses during the pelagic phase of their life history, thus accounting for differences in their otolith microchemistry. This difference was not present during the experimental phase.

\section{Experiment}

Elemental ratios of $\mathrm{Ba} / \mathrm{Ca}$ and $\mathrm{Sr} / \mathrm{Ca}$ varied between otoliths exposed to different water masses during the experiment. The ranking of these ratios, however, varied among years, as indicated by a significant interaction between year and treatment (Table 3). For example, $\mathrm{Ba} / \mathrm{Ca}$ was higher in ocean waters in 2000, similar to that in plume water in 2001 ,
Fig. 2. Elemental ratios $(+\mathrm{SE})$ for the pre-experimental region of the otoliths ( $n=9$ fish). Solid bars denote ocean treatment and shaded bars denote plume treatment for each ratio. (a) $\mathrm{Sr} / \mathrm{Ca}$; (b) $\mathrm{Mg} / \mathrm{Ca} ;(c) \mathrm{Ba} / \mathrm{Ca} ;(d) \mathrm{Mn} / \mathrm{Ca}$.

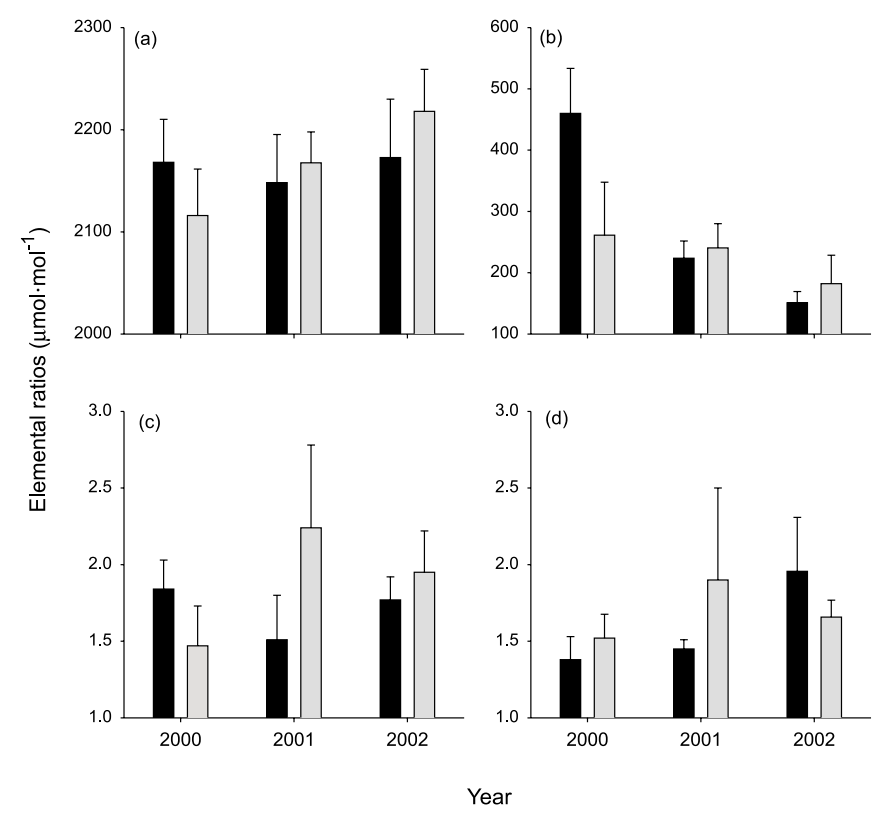

and was much higher than in plume water in 2002 (Fig. 3). No interaction was found for $\mathrm{Mn} / \mathrm{Ca}$ and $\mathrm{Mg} / \mathrm{Ca}$. The $\mathrm{Mg} / \mathrm{Ca}$ ratios for both treatment groups were greater in 2001 than in other years of the experiment.

We were able to obtain good accuracy in classifying fish to water mass treatment using a multivariate (discriminant function analysis) approach. Correct classification rates ranged from $67 \%$ to $100 \%$ for individual years, with 2000 displaying the best separation (Table 4; Fig. 4). The elements driving the separation between treatment groups varied among years, with $\mathrm{Ba} / \mathrm{Ca}$ and $\mathrm{Sr} / \mathrm{Ca}$ contributing in 2000, Sr/Ca being the major discriminator in 2001, and $\mathrm{Ba} / \mathrm{Ca}$ being the major discriminator in 2002 .

\section{Discussion}

This study has demonstrated that the otolith chemistry of reef fish can vary over small spatial scales (hundreds of metres). Although we were not able to directly attribute these differences to water chemistry, it seems likely that variation between plume and oceanic waters at OTI was the source of the noted differences. The separation and isolation of lagoon water may have modified the chemical composition 
Table 3. ANOVA results for $\ln (x+1)$-transformed elemental ratios measured in otoliths during the experimental period.

\begin{tabular}{|c|c|c|c|c|c|c|c|c|c|}
\hline \multirow[b]{2}{*}{ Source } & \multirow[b]{2}{*}{ df } & \multicolumn{2}{|c|}{$\mathrm{Mg} / \mathrm{Ca}$} & \multicolumn{2}{|c|}{$\mathrm{Mn} / \mathrm{Ca}$} & \multicolumn{2}{|c|}{$\mathrm{Sr} / \mathrm{Ca}$} & \multicolumn{2}{|c|}{$\mathrm{Ba} / \mathrm{Ca}$} \\
\hline & & MS & $F$ & MS & $F$ & MS & $F$ & MS & $F$ \\
\hline Year & 2 & 5.64 & $12.24 * *$ & 0.33 & $2.38 \mathrm{~ns}$ & 0.27 & $26.68 * * *$ & 1.61 & $46.95 * * *$ \\
\hline Treatment & 1 & 0.01 & $0.54 \mathrm{~ns}$ & 0.02 & $0.59 \mathrm{~ns}$ & 0.13 & $1.71 \mathrm{~ns}$ & 1.08 & $0.22 \mathrm{~ns}$ \\
\hline Year $\times$ treatment & 2 & 0.02 & $0.04 \mathrm{~ns}$ & 0.02 & $0.17 \mathrm{~ns}$ & 0.08 & $7.62 * *$ & 0.34 & $9.94 * *$ \\
\hline Tank $($ year $\times$ treatment $)$ & 12 & 0.46 & $1.19 \mathrm{~ns}$ & 0.14 & $1.57 \mathrm{~ns}$ & 0.01 & $0.57 \mathrm{~ns}$ & 0.03 & $0.49 \mathrm{~ns}$ \\
\hline Residual & 36 & 0.39 & & 0.39 & & 0.12 & & 0.45 & \\
\hline
\end{tabular}

Note: $* * p<0.01 ; * * * p<0.001 ;$ ns, not significant.

Fig. 3. Elemental ratios (+SE) for the experimental region of the otoliths by year of the experiment and treatment ( $n=9$ fish). Solid bars denote ocean treatment and shaded bars denote plume treatment for each ratio. (a) $\mathrm{Sr} / \mathrm{Ca} ;(b) \mathrm{Mg} / \mathrm{Ca} ;(c) \mathrm{Ba} / \mathrm{Ca}$; (d) $\mathrm{Mn} / \mathrm{Ca}$.

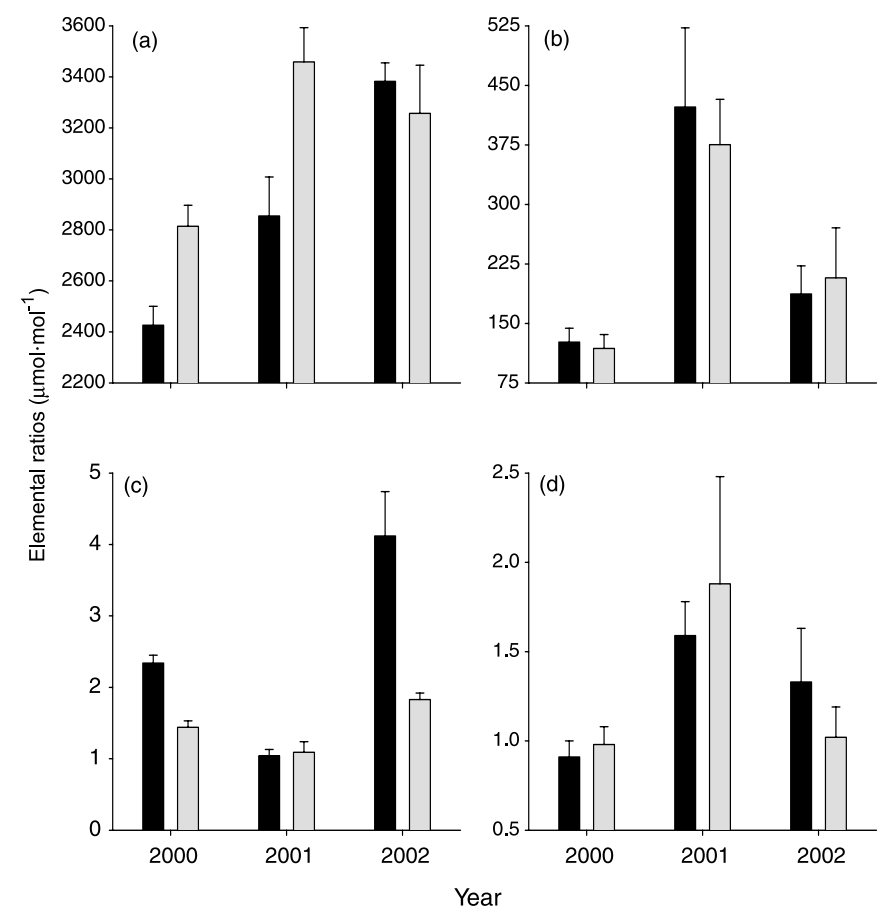

Table 4. Results of the jackknife cross-validation procedures to classify fish from the two experimental treatments by year and with all years combined.

\begin{tabular}{lrllll}
\hline Year & $n$ & df & Ocean & Plume & \multicolumn{1}{l}{$F$} \\
\hline 2000 & 9 & 4,13 & 89 & 100 & $13.37 *$ \\
2001 & 9 & 4,13 & 89 & 67 & $2.34 \mathrm{~ns}$ \\
2002 & 9 & 4,13 & 89 & 67 & $5.79 *$ \\
All years & 54 & 4,49 & 78 & 74 & $5.34^{*}$ \\
\hline
\end{tabular}

Note: Correct classifications are noted as percentages for each experimental treatment group (ocean or plume), and the Pillai trace $F$ statistic resulting from the discriminant function analysis is also noted. $n$, the number of individuals; *, $p<0.01$; ns, not significant.

relative to the surrounding ocean water. Indeed, previous studies have demonstrated that not only can presettlement fish at OTI distinguish between plume and ocean waters (Atema et al. 2002) but also that $P$. coelestis appear to actively avoid settling within plume/lagoon waters (Doherty et
Fig. 4. Jittered dot density plots using the canonical variates derived from the quadratic discriminant function analyses for (a) 2000, (b) 2001, and (c) 2002 ( $n=9$ fish). Circles indicate ocean treatment and triangles indicate plume treatment.
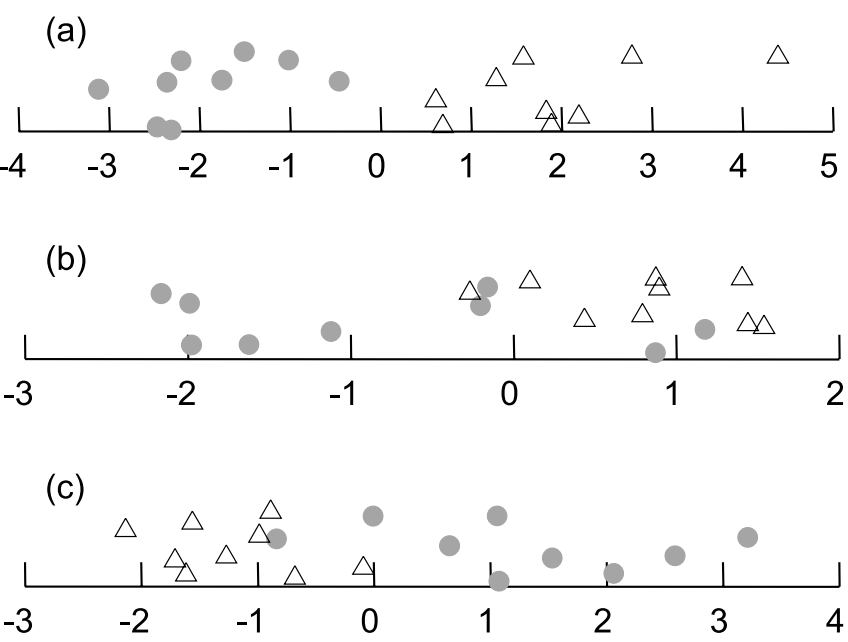

Canonical variate 1

al. 1996). Thus, the two water masses were likely influenced by different mechanisms, which would vary temporally. On a large scale, such mechanisms could include freshwater input (Secor et al. 1995), which is unlikely, since OTI is well offshore $(>80 \mathrm{~km})$, natural biogeochemical cycling of elements (Bruland 1983), and changes in horizontal circulation that may result in the delivery of different packets of water to the area (Doherty et al. 1996; Haskew 2002).

On a more local scale, upwelling and phytoplankton blooms may play a role. Upwelling, which has been documented at OTI (Haskew 2002), has been shown to influence the chemistry of corals (Shen et al. 1987; Lea et al. 1989) and has been suggested as a mechanism for variation in otolith chemistry (Patterson et al. 1999). Settled P. coelestis collected in 2002 from the reef slope $(\sim 20 \mathrm{~m})$ around OTI and several other reefs in the region revealed very high $\mathrm{Ba} / \mathrm{Ca}$ levels in the postsettlement portions of their otoliths $\left(\sim 30 \mu \mathrm{mol} \cdot \mathrm{mol}^{-1}\right)$, suggesting that these fish were in upwelled waters enriched in $\mathrm{Ba}$ (Patterson et al. 2004). Although the $\mathrm{Ba} / \mathrm{Ca}$ levels of the experimental fish were not nearly as high $\left(\sim 4 \mu \mathrm{mol} \cdot \mathrm{mol}^{-1}\right)$ in 2002 , they were much higher than $\mathrm{Ba} / \mathrm{Ca}$ levels measured in the plume treatment fish from 2002, as well as fish from the other years of the experiment. 
A less studied mechanism that may influence plume water is phytoplankton blooms within the OTI lagoon. It has been documented that the precipitation of barite $\left(\mathrm{BaSO}_{4}\right)$, the primary natural source of $\mathrm{Ba}$, is elevated in areas of high productivity and may be facilitated by the decay of phytoplankton blooms (Dehairs et al. 1980; Bishop 1988; Stecher and Kogut 1999). Phytoplankton blooms do occur in the OTI lagoon, particularly during neap tides when oceanic waters do not adequately flush the lagoon for several days (H.M. Patterson and M.J. Kingsford, personal observations). It is possible that these blooms, facilitated by isolation from oceanic waters due to the ponding lagoon and neap tides, reduce the dissolved $\mathrm{Ba}$ in the water column and in fish otoliths. Conversely, cyclones and storms in the areas may facilitate more exchange with ocean waters through storm surge over the reef crest, thus reducing any accumulated differences from blooms or other mechanisms in the lagoon water.

Irrespective of the basis of this difference in otolith chemistry, the consequences are quite clear. Future studies attempting to discriminate reef fish using otolith chemistry or attempting to assign fish to a reef of origin could potentially be confounded by small-scale variation within a reef. Such variation has been documented in several other studies in temperate systems (Thorrold et al. 1998; Kingsford and Gillanders 2000; Wells et al. 2003). Thus, large effect sizes will be required to distinguish reefs or populations given the high variability within a reef. Such effect sizes have been attainable in temperate systems (Thorrold et al. 1998) and may be possible to attain in reef systems (Patterson et al. 2004), although distinct water masses such as those present at OTI due to the ponding lagoon may be less distinct elsewhere. However, low flushing or semienclosed areas may be able to develop chemistries distinct from those of the surrounding water masses, as may areas with seasonal upwelling. Additionally, elemental signatures of reef fish are not temporally stable, compounding the problem. This temporal instability in signatures has also been demonstrated in temperate fish (Campana et al. 2000; Rooker et al. 2001; Gillanders 2002), and thus, signatures being used as stock or nursery markers will need to be recharacterized, likely on annual scales at least, to prevent significant drift between marker characterization and application (Campana et al. 2000; Gillanders 2002). Our results suggest that studies of tropical species will have to recharacterize relevant elemental signatures periodically as well.

In conclusion, this is the first demonstration that reef fish in natural water masses separated by small spatial scales (hundreds of metres) can have distinct otolith chemistries, independent of differences in temperature and food. The variation between fish in the experimental treatments likely represented a complex coupling of multiple factors that remains to be fully explained, although upwelling and phytoplankton blooms within those water masses probably played a role. Our findings have major implications for the use of otolith chemistry in connectivity and stock discrimination applications and suggest small-scale variation and temporal fluctuations should be considered in future studies. Although more research is required to fully understand the complex oceanographic and biological processes that may contribute to water and otolith chemistry, the high resolution possible with LA-ICP-MS is promising for the continued use of otolith chemistry as a tool for examining complex ecological issues.

\section{Acknowledgements}

We thank M. Flood, J. Browne, J. Eagle, J. Hughes, and S. Burgess for assistance in the field. M. Shelley, D. Sinclair, S. Fallon, T. Wyndham, and L. Kinsley provided assistance with the LA-ICP-MS and technical advice. The manuscript was improved by the comments of B. Gillanders and several anonymous reviewers. A Doctoral Merit Research Scholarship from James Cook University, CRC Reef Research Centre Grant, and GBRMPA Augmentative Grant to H.M.P. and an ARC grant to M.J.K. supported this project.

\section{References}

Atema, J., Kingsford, M.J., and Gerlach, G. 2002. Larval reef fish could use odour for detection, retention and orientation to reefs. Mar. Ecol. Prog. Ser. 241: 151-160.

Bath, G.E., Thorrold, S.R., Jones, C.M., Campana, S.E., McLaren, J.W., and Lam, J.W.H. 2000. Strontium and barium uptake in aragonite otoliths of marine fish. Geochim. Cosmochim. Acta, 64: 1705-1714.

Bishop, J.K. 1988. The barite - opal - organic carbon association in oceanic particulate matter. Nature (Lond.), 332: 341-343.

Bruland, K.W. 1983. Trace elements in sea-water. In Chemical oceanography. Vol. 8. Edited by J.P. Riley and R. Chester. Academic Press, London, UK. pp. 157-215.

Campana, S.E. 1999. Chemistry and composition of fish otoliths: pathways, mechanisms and applications. Mar. Ecol. Prog. Ser. 188: $263-297$.

Campana, S.E., Fowler, A.J., and Jones, C.M. 1994. Otolith elemental fingerprinting for stock discrimination of Atlantic cod (Gadus morhua) using laser ablation ICPMS. Can. J. Fish. Aquat. Sci. 51: 1942-1950.

Campana, S.E., Chouinard, G.A., Hanson, J.M., Frechet, A., and Brattey, J. 2000. Otolith elemental fingerprints as biological tracers of fish stocks. Fish. Res. 46: 343-357.

Dehairs, F., Chesselet, R., and Jedwab, J. 1980. Discrete suspended particles of barite and the barium cycle in the open ocean. Earth Planet. Sci. Lett. 49: 528-550.

Doherty, P.J., Kingsford, M.J., Booth, D.J., and Carleton, J. 1996. Habitat selection before settlement by Pomacentrus coelestis. Mar. Freshw. Res. 47: 391-399.

Eggins, S.M., Kinsley, L.P.J., and Shelley, J.M. 1998. Deposition and fractionation processes during atmospheric pressure laser sampling for analysis by ICP-MS. Appl. Surf. Sci. 127-129: 278-286.

Flood, M.J. 2000. Otolith microstructure in pre- and post-settlement Pomacentrus coelestis (Pisces: Pomacentridae). Honours thesis, University of Sydney, Sydney, Australia.

Gillanders, B.M. 2002. Temporal and spatial variability in elemental composition of otoliths: implications for determining stock identity and connectivity of populations. Can. J. Fish. Aquat. Sci. 59: 669-679.

Gillanders, B.M., and Kingsford, M.J. 1996. Elements in otoliths may elucidate the contribution of estuarine recruitment to sustaining coastal reef populations of a temperate reef fish. Mar. Ecol. Prog. Ser. 141:13-20. 
Gillanders, B.M., and Kingsford, M.J. 2000. Elemental fingerprints of otoliths may distinguish estuarine "nursery" habitats. Mar. Ecol. Prog. Ser. 201: 273-286.

Haskew, R. 2002. Circulation around One Tree Reef, Great Barrier Reef, Australia. M.Sc. thesis, University of Waikato, Hamilton, New Zealand.

Lea, D.W., Shen, G.T., and Boyle, E.A. 1989. Coralline barium records temporal variability in equatorial Pacific upwelling. Nature (Lond.), 340: 373-376.

Ludington, C.A. 1979. Tidal modifications and associated circulation in a platform reef lagoon. Aust. J. Mar. Freshw. Res. 30: 425-430.

Kingsford, M.J., and Gillanders, B.M. 2000. Variation in concentrations of trace elements in the otoliths and eye lenses of a temperate reef fish, Parma microlepis as a function of depth, spatial scale and age. Mar. Biol. 137: 403-414.

Knowlton, N. 2001. The future of coral reefs. Proc. Nat. Acad. Sci. U.S.A. 98: 5419-5425.

Maxwell, W.G.H. 1968. Atlas of the Great Barrier Reef. Elselvier, Amsterdam, Netherlands.

Patterson, H.M., Thorrold, S.R., and Shenker, J.M. 1999. Analysis of otolith chemistry in Nassau grouper (Epinephelus striatus) from the Bahamas and Belize using solution-based ICP-MS. Coral Reefs, 18: 171-178.

Patterson, H.M., Kingsford, M.J., and McCulloch, M.T. 2004. Elemental signatures of Pomacentrus coelestis at multiple spatial scales on the Great Barrier. Mar. Ecol. Prog. Ser. 270: 229-239.

Patterson, W.P., Smith, G.R., and Lohmann, K.C. 1993. Continental paleothermometry and seasonality using the isotopic composition of aragonite otoliths of freshwater fishes. Geophys. Monogr. 78: 191-202.

Rooker, J.R., Secor, D.H., Zdanowicz, V.S., and Itoh, T. 2001. Discrimination of northern bluefin tuna from nursery areas in the Pacific Ocean using otolith chemistry. Mar. Ecol. Prog. Ser. 218: 275-282.

Secor, D.H., Henderson-Arzapalo, A., and Piccoli, P.M. 1995. Can otolith microchemistry chart patterns of migration and habitat utilization in anadromous fishes? J. Exp. Mar. Biol. Ecol. 192: $15-33$.

Shen, G.T., Boyle, E.A., and Lea, D.W. 1987. Cadmium in corals as a tracer of historical upwelling and industrial fallout. Nature (Lond.), 328: 794-796.

Sinclair, D.J. 1999. High spatial-resolution analysis of trace elements in corals using laser ablation ICP-MS. Ph.D. thesis, The Australian National University, Canberra, Australia.

Stecher, H.A., and Kogut, M.B. 1999. Rapid barium removal in the Delaware estuary. Geochim. Cosmochim. Acta, 63: 1003-1012.

Swearer, S.E., Caselle, J.E., Lea, D.W., and Warner, R.R. 1999. Larval retention and recruitment in an island population of a coral-reef fish. Nature (Lond.), 402: 799-802.

Thorrold, S.R., and Shuttleworth, S. 2000. In situ analysis of trace elements and isotope ratios in fish otoliths using laser ablation sector field inductively coupled plasma mass spectrometry. Can. J. Fish. Aquat. Sci. 57: 1232-1242.

Thorrold, S.R., Jones, C.M., Campana, S.E., McLaren, J.W., and Lam, J.H.W. 1998. Trace element signatures in otoliths record natal river of juvenile American shad (Alosa sapidissima). Limnol. Oceanogr. 43: 1826-1835.

Thorrold, S.R., Latkoczy, C., Swart, P.K., and Jones, C.M. 2001. Natal homing in a marine fish metapopulation. Science (Wash., D.C.), 291: 297-299.

Thorrold, S.R., Jones, G.P., Hellberg, M.E., Burton, R.S., Swearer, S.E., Neigel, J.E., Morgan, S.G., and Warner, R.R. 2002. Quantifying larval retention and connectivity in marine populations with artificial and natural markers. Bull. Mar. Sci. 70(Suppl.): 291-308.

Wells, B.K., Rieman, B.E., Clayton, J.L., Horan, D.L., and Jones, C.M. 2003. Relationships between water, otolith, and scale chemistries of westslope cutthroat trout from the Coeur d'Alene River, Idaho: the potential application of hard-part chemistry to describe movements in freshwater. Trans. Am. Fish Soc. 132: 409-424. 